\title{
The Relationship Between Physical Fitness, Discipline and Motivation of UNNES Security Performance
}

\author{
Aristiyanto $^{1}$ \\ \{aristiyanto01@gmail.com $\left.{ }^{1}\right\}$ \\ Universitas Ngudi Waluyo, Semarang, Indonesia ${ }^{1}$
}

\begin{abstract}
This study aims to analyze and describe the relationship between the independent variables and the dependent variable. This type of research uses quantitative correlational. The number of samples used was 61 from a population of 109 members of UNNES security s. The instrument used was the kesamaptaan test and questionnaire sheets. Data analysis using correlation and regression, the results showed: (1) physical fitness made an effective contribution of 10,8\%, (2) discipline made an effective contribution of 46,3\%, (3) motivation made an effective contribution of $4,2 \%$, (4) jointly physical fitness, work discipline and work motivation contributed $61,4 \%$ to the performance of UNNES Security members. Recommendations from this study are that efforts should be made to improve fitness physical, work discipline and work motivation UNNES Security together in order to improve the performance of Security Semarang State University.
\end{abstract}

Keywords: Physical Fitness, Discipline, Motivation, Performance

\section{Introduction}

Security $s$ in this case are Police partners who carry out limited police functions, in the context of empowering independent self-security security as Police partners in carrying out tasks in special coordination, to increase legal awareness and improve security in their environment [1]. Safeguards as part of overall management, which involves the organizational structure, planning, responsibilities, implementation, procedures, processes and resources needed for the development of planning, winning, reviewing and maintaining security policies in a safe, efficient and productive manner [2].

Semarang State University as one of the leading LPTKs in Indonesia as stated in its mission; organize and develop education in educational and non-educational programs which are superior in view of conservation and international reputation. Supported by human resources totaling more than 1090 lecturers, and 32,913 students [3]. Comparison of the number of UNNES Security against Lecturers and Students is 1 person compared to 311 people [4]. 
UNNES security performance can be optimized if supported by good physical fitness in addition to other factors, in some previous studies physical fitness is a supporting factor for officers to carry out their duties optimally [5.6]. Physical fitness is a condition that reflects one's ability to perform tasks productively without experiencing significant exhaustion [7 - 9].

Discipline in this case as one of the factors has an influence on good performance [10]. Work discipline is an attitude and behavior that shows employee obedience to organizational regulations [11]. UNNES Security Guard requires work discipline to support the implementation of basic tasks and functions related to security in the work environment of UNNES. Work discipline directs members of UNNES security guards to obey the norms, code of ethics, statutory regulations and official regulations that apply in UNNES.

Another factor that also determines performance is work motivation [12]. Motivation is the strength that is in a person, which encourages behavior to take action [13]. There is a positive relationship between achievement motivation and work performance [14]. It is suspected that the emergence of good work motivation from members of UNNES security will result in good performance as well.

\section{Methods}

This type of research is quantitative correlational. The population in this study were 109 members of the Semarang State University Security Guard. The sampling technique is done by purposive sampling technique [15]. The sample size was 61 members of the UNNES security guard. The research instrument used for physical fitness was a safety test A with a 12-minute run (cooper test) and a safety test B with pull ups, sit ups, pushups, shuttle runs. Research instruments to determine the discipline, motivation and performance of UNNES Security Guard with questionnaire sheets, the use of instruments and measurement methods in more detail will be explained below;

\subsection{Measurement of physical fitness}

The tool used is the A and B Kesamaptaan test [16]. In the A Kesamaptaan test, members of the UNNES security carried out a 12-minute run which was then measured by the distance of his run, then adjusted to the existing norms. For Pull Up, sit up, push up, and shuttle run tests, the testee tests once and then is given the opportunity to carry out the test 3 times, then the best value is taken and adjusted to the existing test norms. 


\subsection{Measurement of dicipline, motivation \& performance}

The instrument used in measuring discipline, motivation and performance is a questionnaire, which is a written statement that is used to obtain information from respondents in the sense of reports about their personalities, or things they know [17]. A valid and reliable instrument was obtained by first testing the questionnaire against members of the UNNES security as a non-sample population. The results of the calculation of the validity of the questionnaire on the variables of discipline, motivation, and performance on each of the questions from the respondents showed the value of rcount> rtable $(0.254)$ at a significance level of $5 \%$, thus meaning the questionnaire was declared valid.

The research data is stated to be reliable if the instrument shows its consistency, in this case is the discipline, motivation, and performance of UNNES security guards. Based on the calculation results of the instrument analysis data the disciplinary variable shows the value of cronbach's alpha 0.794 greater than $r_{\text {table }}$ that is 0.254 , the motivational variable instrument shows the value of cronbach's alpha 0.901 greater than $\mathrm{r}_{\text {table }}$ that is 0.254 , the performance variable instrument shows the value of cronbach's alpha 0.943 greater than $r_{\text {table }}$ that is 0.254 , this means the research instrument is declared reliable or in other words the instrument is of consistent value.

\subsection{Data Analysis}

Data from the results of measurements of physical fitness, discipline, motivation and performance results of UNNES security guards were analyzed univariately to obtain an overview of basic data with the aim of knowing the frequency distribution of all variables and facilitating further analysis. Then the bivariate analysis is performed using the Pearson correlation test which aims to determine the relationship between each variable. Data analysis in this study uses regression analysis techniques and correlation analysis. To get the right analytical results, testing the analysis requirements is needed in order to obtain the following confidence:

1) the data is normally distributed, so that the normality test is done, after the data is analyzed it is found that the Asymp value. Sig $=0.174>0.05$ so the data is normally distributed. 2) between the independent variable data and the dependent variable has a linear relationship, so that the linearity test is performed. The results of data analysis found that; the value of linearity Y to X1 Sig $=0,000<0.05$ This means that the linear relationship between $\mathrm{Y}$ and $\mathrm{X} 1$. Y linearity value of X2 Sig $=0,000<0.05$ means there is a linear relationship between $\mathrm{Y}$ and X2. Y linearity value of X3 Sig $=0,000$ $<0.05$ which means there is a linear relationship between $Y$ and X3. 3) the data is homogeneous, so the homogeneity test is carried out with the Levense test and based on the results of data analysis, the value for $\mathrm{Y}$ to $\mathrm{X} 1$ is Sig $=0.103>0.05$. Y with respect to $\mathrm{X} 2 \mathrm{Sig}=0.16>0.05$. Y with respect to $\mathrm{X} 3 \mathrm{Sig}=0.111>0.05$ so that all variables are declared homogeneous. 


\section{Results and discussions}

This study involved 61 members of UNNES security guards as research subjects, all of whom were male, according to the level of education there were 11 security guards who had just taken Pragada, 47 were Gada Pratama certified and 3 were Gada Madya certified. Based on their tenure, 14 people have 1-5 years of service, 23 with 6-10 years, 16 people with 11-15 years and 8 people with more than 15 years. General description of the characteristics of research subjects can be seen in table 1 .

Table 1. Overview of Characteristics of Resarch Subjects

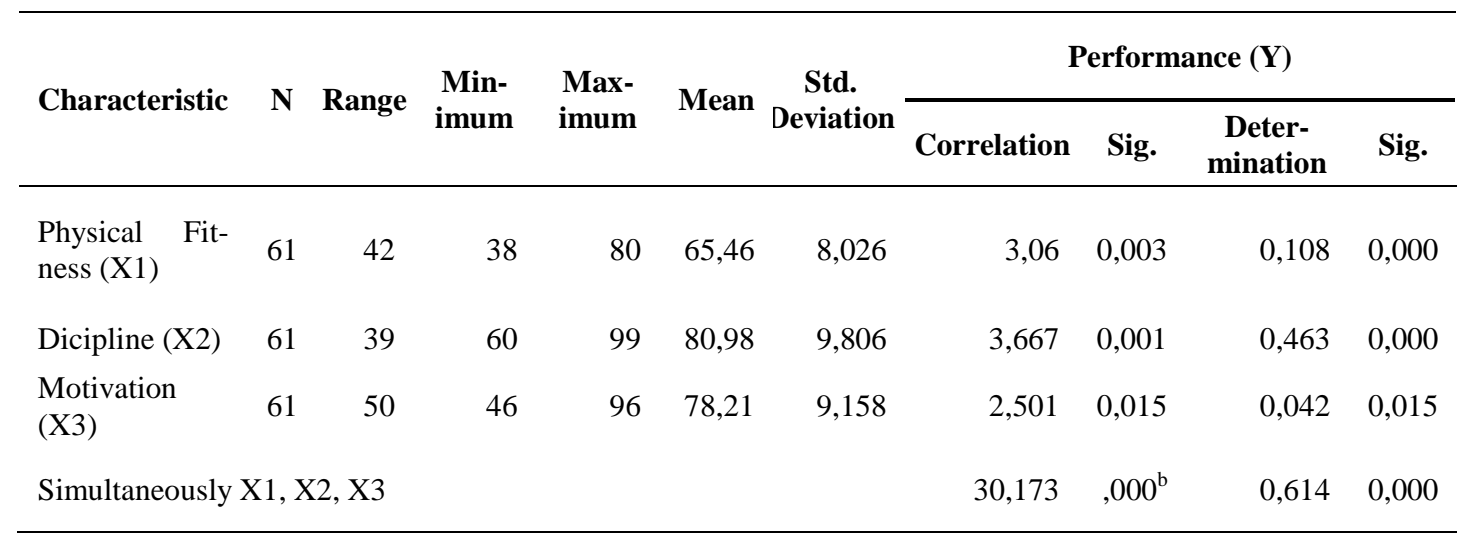

\subsection{Correlation between physical fitness with performance}

From the results of the $t$ test in table 1 above, obtained t value $=3.060$ with the value of Sig / P Value $=0.003<0.05$ this means that there is a positive and significant relationship which means supporting the research hypothesis. Based on these results it means that there is a significant influence between physical fitness on the performance of UNNES security guards.

The results of the analysis indicate a positive relationship between physical fitness variables (X1) and performance variables (Y), this means that the physical fitness of UNNES security will be directly proportional to its performance. Means that if every member of UNNES security guard who has physical fitness in a good category, it will affect the performance improvement. In other words, the performance of UNNES security will increase along with the increase in physical fitness.

Effective contribution of physical fitness variables to performance variables can be determined by looking at how large the determinant coefficient ( $R$ Square Change). Based on table 1 above, the effective contribution of physical fitness to performance is R Square Change $=0.108$ or an effective contribution of $10.8 \%$.

\subsection{Correlation between dicipline with performance}

From the results of the $t$ test in table 1 , the calculated value of $t=3.667$ with $\mathrm{Sig} /$ $\mathrm{P}$ Value $=0.001<0.05$ means that there is a positive and significant relationship which means that supports the research hypothesis. Based on these results it means that there is a significant influence between discipline on the performance of UNNES 
security guards. Effective contribution of disciplinary variables to performance variables can be determined by looking at how large the determinant coefficient (R Square Change) in table 1 above, the effective contribution of discipline to performance is $\mathrm{R}$ Square Change $=0.463$ or an effective contribution of $46.3 \%$.

\subsection{Correlation between motivation with performance}

From the results of the test of motivation variables on performance in table 1 above, the value of $\mathrm{t}$ test $=2.501$ with $\mathrm{Sig} / \mathrm{P}$ Value $=0.015<0.05$ means that there is a positive and significant relationship which means that supports the research hypothesis. Based on these results it means that there is a significant influence between discipline on the performance of UNNES security guards. Effective contribution of disciplinary variables to performance variables can be determined by looking at how large the determinant coefficient ( $\mathrm{R}$ Square Change) in table 1 above, the effective contribution of discipline to performance is R Square Change $=0.042$ or an effective contribution of $4.2 \%$.

\subsection{Correlation between physical fitness, dicipline and motivation with perfor- mance}

$\mathrm{F}$ value for simultaneous test where $\mathrm{F}=30,173$ with significance $=0,000<0.05$ This means that the independent variable $(\mathrm{X})$ simultaneously has an influence on the dependent variable (Y), can be seen in table 1. The effective contribution of the independent variable together with respect to dependent variable is $\mathrm{R}$ Square $=0.614$, this means that the independent variable jointly contributes an effective contribution of $61.4 \%$ to the dependent variable (see in the table 1 above).

\section{Conclusions}

It can be concluded that physical fitness, discipline and work motivation have an influence on performance by making an effective contribution of $61.4 \%$. While the remaining $36.6 \%$ is explained by other variables not examined in this study. It should be noted that there are other factors that also have a relationship between security guard performance. For this reason, it is hoped that in subsequent studies it will be able to explore more of these factors so that they will further enrich the findings of the study and broaden the treasury of science.

\section{Acknowledgements}

Thank you are conveyed to the UNNES Security Guards who have agreed to become research subjects. Researchers are also grateful to all leaders of UNNES who have given research permission, so that this research can run well.

\section{References}

[1] Satpam LP. Kumpulan Materi Diklat Satpam Tingkat Gada Pratama Pola 232 Jam. Semarang: PT. Produktif Citra Sukses; 2016.

[2] Satpam LP. Kumpulan Materi Diklat Satpam Tingkat Gada Utama Pola 232 Jam. Semarang: PT. Produktif Citra Sukses; 2017. 
[3] Simpeg UNNES, http//:simpeg.unnes.ac.id, last accessed 18 June 2020.

[4] UNNES Dalam Data, http//:unnes.ac.id, last accessed 18 June 2020.

[5] Sumaesah. Upaya Meningkatkan Kemampuan Kesamaptaan Jasmani Personel Polrestabes Semarang Guna Mendukung Tugas Operasional Kepolisian. Sukabumi: Sekolah Inspektur Polisi Sukabumi; 2014.

[6] Utami S. R. Hubungan Antara Status Gizi dan Tingkat Kebugaran Jasmani dengan Produktivitas Kerja Pada Tenaga Kerja Wanita Unit Spinning 1 Bagian Winding PT. Apac Inti Corpora Bawen. UJPH. 2014; 3(4):39-47.

[7] Ismaryati. Tes dan Pengukuran Olahraga. Surakarta: Lembaga Pengembangan Pendidikan UNS dan UPT Penerbitan dan Percetakan UNS; 2006.

[8] Dangsina M., Rosmalina Y., Permaesih D., Herman S. Cara Praktis Pendugaan Tingkat Kesegaran Jasmani. Bul. Penel. Kes. 2001; 29(4):174-183.

[9] Caspersen C. J., Powell K. E., Christenson, G. M. Physical activity, exercise, and physical fitness: definitions and distinctions for health-related research. Public Health Rep. 1985; 100(2):126-131.

[10] Wulandari. Keterampilan Kerja, Kedisiplinan Kerja dan Efektifitas Komunikasi sebagai Prediktor Produktivitas Kerja Karyawan Bagian Produksi PT. Phillips Industries Batam. Jakarta: Universitas Terbuka; 2013.

[11] Wungubelen, R. L. Pengaruh Kepemimpinan dan Disiplin Terhadap Kinerja Pegawai pada Inspektorat Kabupaten Flores Timur. Jakarta: Universitas Terbuka; 2013.

[12] Mulyasa E. Penelitian Tindakan Kelas: Meningkatkan Produktivitas Sekolah. Bandung: Remaja Rosdakarya; 2009.

[13] Widodo S. E. Manajemen Pengembangan Sumber Daya Manusia, 1st Ed. Yogyakarta: Pustaka Pelajar; 2015

[14] Mangkunegara A. P. Manajemen Sumber Daya Manusia. Bandung: PT. Remaja Rosdar Karya; 2005.

[15] Arikunto S. Prosedur Penelitian Suatu Pendekatan Praktik. Jakarta: PT. Rhineka Cipta; 2013.

[16] POLRI M. Pedoman Administrasi Ujian Kesamaptaan Jasmani dan Beladiri Polri bagi Pegawai Negeri pada Polri. Jakarta: Markas Besar Kepolisian Negara Republik Indonesia; 2004.

[17] Arikunto S. Dasar-Dasar Evaluasi Pendidikan. Jakarta: Bumi Aksara; 2013. 